\title{
WASTE MANAGEMENT IN BRONZE AGE EUROPE
}

\author{
FILIP HAVLÍČEK ${ }^{1}$, MARTIN KUČA $^{2}$ \\ ${ }^{I}$ Dep. of Environmental Studies, Masaryk Uni., Brno, Czech Republic, e-mail: \\ filipovo.havlickovo@gmail.cz \\ ${ }^{2}$ Town Museum Moravský Krumlov, Moravský Krumlov, Czech Republic, e-mail: \\ makku@email.cz.
}

Received: $3^{\text {rd }}$ April 2017, Accepted: $26^{\text {th }}$ April 2017

\section{Мотто}

Civilization is a limitless multiplication of unnecessary necessities.

Mark Twain

\begin{abstract}
This article deals with the relationship between humans and waste in the Bronze Age. Based on selected examples of waste management strategies from the European Bronze Age, it presents an overview of different strategies. In comparison with the preceding Stone Age, a new type of material began to appear: metal. The process involved in producing metal objects, however, brought with it the appearance of a specific type of waste material that is indelibly linked to the production of metal. This article also deals with the significance of ritualized social activities in the Bronze Age, which materialized in waste and waste management strategies.
\end{abstract}

Keywords: Waste management, waste, Bronze Age, Archaeology, Anthropology, Environmental History, Europe

\section{INTRODUCTION}

The development of waste management strategies seems to be an anthropological constant that can be documented in every period of human history stretching back to the Paleolithic (Havlíček, 2015). Anthropologist G. P. Murdock also includes the creation of waste strategies on his extensive list of characteristics shared by all historic and contemporary cultures (Murdock, 1945). This phenomenon is likely, in a certain sense, a result of evolution, considering the development of our senses, which call our attention to environmental pollution. Conscious waste management and the disposal of waste likely developed as a way to prevent disease and to protect against odors, insects, and wild animals (Bilitewski, 1997).

When considering the variability in waste strategies and how waste and odors are perceived, many regional and cultural differences related to the diversity of environments in which different ethnicities live and, most certainly, differences in their social rules, must be taken into account. 
The Bronze Age is generally considered to be the last phase in humankind's prehistory, during which significant changes in the social environment occurred, which in Central Europe can be observed, for example, in "proto-urban" cultures, whose bearers were in contact with contemporary centers of advanced civilization in the Mediterranean area, characterized by the Minoan and Mycenaean cultures. Even though the Bronze Age is considered a turning point in time, in which "history sped up," it is necessary to take into account that this period in human history is in a certain sense immediately connected to the technological knowledge of the Paleolithic and Neolithic. Stone, the dominant material for producing artefacts was gradually replaced with metals, which certainly contributed to the significant social changes.

In Central Europe we encounter the first metals in the Lengyel culture (cf. Schenk et al, . 2007; Dobeš et al., 2010). At first, their use was limited to non-utilitarian artefacts. The actual beginnings of metallurgy in this region can be traced back to the Eneolithic (Rožnovský \& Šmíd, 2013; Dobeš, 2013). Discoveries of crucibles and casting vessels are evidence (Točík \& Bublová, 1985; Gumiński, 1989; Obereder et al., 1993).

Generally, artefacts significantly contribute to forming social relationships and through them the social identity of individuals is created. But metal itself could create a certain type of tension in society, which was reflected in social stratification.

The fact that the production of bronze artefacts is characterized by a specialized technological procedure may have played a role. In comparison with stone, the percentage of the population able to create a bronze artefact with their own hands decreased drastically. The technology used to process metals also resulted in new economic relationships, which were then reflected in the power structures of this period (Sherratt, 1997). Production specialization has since advanced to the point where today most inhabitants of technologically developed countries can no longer make most of the items they need for daily life.

Thanks to its composition, bronze compensates for copper's softness. The use of metals enabled a greater variety of artefacts to be made and, considering the material qualities of metals, it also facilitated better recycling (especially when compared to chipped stone industries). During the short, but dynamic Bronze Age in Europe, the seeds were sown for the following Iron Age. In Europe, we can observe ethnogenetic process that "led to the final breakup of the Indo-European language unit and the emergence of historical ethnicities" (Podborský, 1997; 118). Also in the Bronze Age, as opposed to in the preceding period, social stratification became clearer (Kristiansen \& Larsson, 2005).

\section{Mining Waste}

Mining activities create waste materials, whether it is waste from mining itself or whether it is waste from the subsequent processing of the mined material. We attempted to summarize examples of mining and subsequent waste treatment in the preceding lower Stone Age in an article on waste in the Neolithic and Chalcolithic (Havlíček \& Kuča, 2017).

Even though we have records of relatively sophisticated vertical mine works already from the Neolithic (e.g., Krzemionki in Poland [Bąbel 2008]) and underground mining is not connected with innovations until the so-called upper prehistoric period, it is worth mentioning here the Krumlovský les site, a very remarkable mining site. However, if we were to just characterize the activities that were undertaken here as mining, we would be simplifying matters to a great degree. Here at what was likely one of the biggest mining sites in prehistoric Europe (and probably a religious and socio-symbolic center as well) (Oliva, 2010), chert was mined from the Paleolithic until the early Iron Age. There is a paradox, for it seems that the massive amount of chert that was mined here was, from a certain point in time 
(the end of the Chalcolithic), left here and was some kind of symbolic material. For the purposes of this article, we will be interested in the Bronze Age at this site.

The concentration of waste from chipped stone industries was so enormous that researchers in the 1930s considered it to consist of mere pseudo-artefacts (Oliva, 2010). The extreme amount of artefacts produced here reflected their value in the social and symbolic realms. It seems that the more difficult it was to mine a certain material the greater its value was. As Martin Olivia, the leader of a long-term archeological excavation project, writes: "Today it is clear that not even mining in other exploitation sites had this practical sense and was focused on producing items of social significance, whose "charisma" or "mana" clearly increased the harder the material was to access and with the amount of work it took. What was important was the energy consumed by traveling to the source, the organization of mass communal activities, the production of the artefact itself (like all other artefacts left at the site), removing the products, exchanging them, etc." (Oliva, 2010; 334).

In the Bronze Age we can also witness a peculiar phenomenon. An extremely large amount of stone was mined, chipped, and left in one place. In close proximity to mine shafts near work spaces thick layers of waste from producing chipped stone tools were found. This large mass of waste is localized on summits, on promontories, and in the eastern part of the forest (Oliva, 2010). Oliva also states that most of the production waste is located near places that are suitable for sitting, such as boulders. Even though waste from stone tool production is concentrated in certain spots, the site does not give off the impression that an organized waste management strategy was implemented here. It is, however, worth mentioning the fact that part of these mine works were at one point in time filled in and thus conserved (interview with Martin Oliva). This model brings to mind what is most likely the oldest prehistoric temple building in the world at Göbekli Tepe in today's Turkey. Here, after much effort was put into building this enormous structure, the entire building was covered in clay and waste (Peters \& Schmidt, 2004). This fact could stimulate us to view the entire site as a place with greater social significance than economic, although on first glimpse one would expect a mining site to be of greater economic importance. Considering the sheer amount of waste material here, it had to play some kind of role. We do not know, however, which role.

Whether these findings are the result of a primary waste strategy (when waste stays in the place of its creation) or of a secondary waste strategy (when waste is brought to a certain place to be disposed) in the sense of Neustupný's theory of waste sites (2007) cannot be unambiguously determined. Thus, unfortunately we cannot even answer the question whether waste as the residue of some kind of symbolic act of stone chipping stayed in a special place intended for this act, or whether it was moved and deposited in another place.

On the other hand mine shafts were often filled with mined stones (Oliva, 2010). But again to speak here about any kind of waste strategy is very complicated.

Considering the fact that bronze gradually pushed stone aside, mining is seemingly weighed down with nostalgia for chipped stone tools, with which practically all preceding generations worked and were in daily contact with. Stone itself may have had an uncapturable symbolism, which once it came into contact with this new era of metal artefacts generated this material expression.

The activities in the Krumlovský les Forest connected with mining and chipping stone are difficult to interpret, especially from a cultural or social perspective. In the light of this fact, it would be perhaps better to interpret this site, at least its use in the Bronze Age, more as a cultural, social, or religious center rather than a mere mining site. Oliva's (2010) explanation that the social stability of a certain ideology was maintained through organized free time activities seems to be on point. We can observe analogous situations in today's world, for example, the construction of megalomaniac buildings and senseless projects, such 
as unused four-lane highways in North Korea or perhaps even Czechoslovakia's Spartakiad events in the twentieth century (Oliva, 2010). We assume that this explanation comes closest to what actually transpired in the Krumlovský les Forest in Bronze Age South Moravia.

\section{Metal Processing}

During metal processing waste is produced in the form of slag, the non-metal material left over after smelting ore. This material is made up of the impurities contained in ore that are separated and removed from the pure metal. Metallurgical slag is usually evidence of a certain type of metal-working activity. Metallurgical slag demonstrates great strength, thanks to which it is easily conserved and preserved. In archaeological terminology, slag is categorized as an ecofact, which is an item produced by human activity, but-not intentionally made; thus, unlike artefacts, ecofacts are the by-products of human activities.

Deposited slag is often found in great quantities. The amount of unearthed ecofacts depends on many factors, including accessibility of metal ores. The intensity of metal production can be manifested in large multilayer waste mounds made of slag (Ben-Yosef et al., 2008).

This material was likely classified as permanent waste material considering that it could only be recycled for very marginal uses. Rather, only slag that was created during technologically less advanced metal-making processes could be reused. One possible use of slag was to grind it up and use it to color glass or beads.

Bronze items are practically never found amongst common waste materials, not even in the form of scrap, due to this material's rarity. This material could be reworked. What however is found are the deposits of bronze scrap collected in one place that were intended to be resmelted and reused to make artefacts.

Recycling could have had a ritual character in certain places in the Bronze Age. This is likely documented at the Cyprus Minoan culture site of Kition. Based on the amount of discovered scrap metal in temples, the authors of the study theorize about a connection between ritual smelting and the recycling of metal (Karageorghis \& Kassianidou, 1999).

They also theorize about the recycling of bones, which were added as fuel for processes that required making high temperatures, such as smelting and casting copper alloys (Karageorghis \& Kassianidou, 1999). Piles of bone dust were discovered at the Kition site in a complex of five temples; they were most likely the bones of sacrificed animals. In this manner, local inhabitants could get rid of animal bones and at the same time they did not have to search for fuel (Karageorghis \& Kassianidou, 1999). The presence of phosphorous and calcium indicate the high fusibility of the metal, and thus smoother, homogenous metal surfaces could be created (Karageorghis \& Kassianidou, 1999).

Toxic compounds in the form of heavy metals are produced in metallurgical processes and thus such activities had the potential to pollute soil at sites where they were performed. Such consequences were one of the first environmental problems in history. Heavy metals contained in the soil found their way into food, and from there into the human body.

Health problems such as infertility occurred and many people died prematurely due to high concentrations of lead and copper (Grattan et al, 2016). Even though Grattan et al. focus on the earlier Neolithic period, it is likely that in the Bronze Age the concentrations of heavy metals were similar, if not higher.

\section{From Crete to the Orkneys}

Ancient Aegean cultures coincided with the Bronze Age and thus they should be mentioned at least briefly. One type of activity related to sanitation, waste production, and waste management is the acquisition of good sources of water for various activities 
connected to daily life. Angelakis and Zheng attribute the advanced development of the water supply system of Aegean cultures to their close contact with Egyptian civilization, which they drew inspiration from (Angelakis \& Zheng, 2015). Minoan culture was certainly one of the first cultures in Europe to use, at least to some extent, a system of underground clay pipes (Angelakis et al, 2014). For example, at the Cretan palace of Knossos the water-pipe system could accommodate the inflow of clean water. A sewage system drained wastewater and excrement away from this structure. The chambers of the rulers were built with baths that were connected to the drainage system under the palace (Melosi, 1981). A clever system for cleaning the sewage system was implemented: the pipes were flushed with rainwater collected on the palace's roofs (Angelakis et al., 2014). For example, at the Palace of Faistos there were cisterns of water that was cleaned by having it flow through ceramic filters containing sand (Angelakis et al., 2014). Despite the advanced development of Aegean cultures, it cannot be assumed that all members of society were blessed with this convenience of civilization; it is likely that only wealthy elites could afford such luxury.

From the perspective of waste policy, Minoan civilization established waste dumps, which were periodically covered with a layer of soil, and thus large waste pits were created (Wilson, 1977 in Pichtel, 2005).

We can observe another form of water management implemented with the intention of improving sanitary conditions on the Orkney Islands in the Bronze Age, which are more than $2,500 \mathrm{~km}$ away from the island of Crete. Even though the Orkney Islands are mainly famous for Neolithic sites, such as Skara Brae, a large amount of unique Bronze Age data has been preserved here thanks to the stone-based building technologies used. One remarkable example is a preserved specialized Bronze Age structure from the Links of Noltland site that seems to have been something like a bath or a sauna. The technical infrastructure of the facilities has been studied; it included a cistern, where water was probably heated and steam produced. It is assumed that activities for purifying the body took place here; perhaps women may have given birth here and sick or old people might have spent time here as well (Barfield et al., 1987). Water was heated and stream produced most likely by throwing stones heated in fire into the central water cistern (Barfield et al., 1987).

\section{Waste in Settlements}

Martin Kuna and Andrea Němcová have dedicated an extensive book to studying the structures that were created as a consequence of different means of handling settlement waste (Kuna \& Němcová, 2012). In it, they examine archaeological material from a Bronze Age site in Roztoky u Prahy; it is necessary to mention that it is a relatively unique site in the Czech lands.

Aboveground parts of dwellings that could help explain the relationship to uncovered buried objects have not been preserved. This poses a problem common in archeology. As Kuna and Němcová assume (in keeping with Schiffer's behavioural archeology ${ }^{1}$ ), on the basis of the arrangement of artefacts in waste, the original arrangement of the settlement can be determined (Kuna \& Němcová, 2012). The authors noticed a regularity in the composition of the findings, which they refer to as structured depositions (Kuna \& Němcová, 2012). The question, however, is to what extent is the preservation of an item based on its original function or material or plans for its further use affected by symbolic behavior and to what extent by purely functional (pragmatic) behavior.

Based on the research conducted in Roztoky the authors assume certain symbolic or functional behaviour for "... functional types of ceramics, animal bones based on type of

\footnotetext{
${ }^{1}$ For more details, see Behavioral Archeology (Schiffer, 1976).
} 
animal and bones based on use in food preparation (meaty parts of the body vs. harder to use waste), the amount and type of daub, or other artefacts" (Kuna \& Němcová, 2012; 226). However, when the authors subjected the above-described material to a more detailed analysis, they came to the conclusion that for none of these types of findings could they clearly identify a structure that maintained functional differences in waste in individual parts of the settlement (Kuna \& Němcová, 2012).

However, they do make a fundamental conclusion: "recessed structures were not filled in through random processes and material from the immediate vicinity, but [they were filled] systematically, at once, and with material from waste areas, where waste was concentrated from various activities in the settlement" (Kuna \& Němcová, 2012; 226). This conclusion de facto assumes organized waste management at the Bronze Age settlement in Roztoky $u$ Prahy.

Laura Dietrich has made remarkable findings in her spatial analysis of fragments of ceramic vessels from the Romanian Bronze Age site of Rotbov. Dietrich identifies two groups of waste: the "remnants of everyday life" and structured deposits (whose creation is affected by economic, ritual, and symbolic factors) and considers it fundamental to differentiate based on a spatial analysis of the individual parts of sites (dwellings, production spaces, etc.) (Dietrich, 2016). Here she refers to the work of Ulrike Sommer, who differentiates between an active zone, a passive zone, and a waste storage zone (or the arrangement of waste based on price, size, cleanliness, or dangerousness) (Sommer, 1990). Recognizing such differentiations in the field, however, is often complicated by the incomplete preservation of the sources, missing data, and state of research (Dietrich, 2016).

L. Dietrich in Rotbov has discovered two differing models of waste management in two adjacent time periods. She points out the strict rules for handling waste in the middle of the Bronze Age, which included the regular cleaning of public spaces. Based on the statistical assessment of shard fragments, it was proven that large shards from these places were likely deposited in waste pits next to houses (Dietrich, 2016). However, some large fragments were found in homes and were certainly meant to be reused (Dietrich, 2016).

In the late Bronze Age, ceramic waste begins to appear in public spaces (Dietrich, 2016), which demonstrates a likely change in the social agreement on waste management at this specific site. Pits, which previously were used at least partially for waste, changed in shape, were found farther from homes, and there is no proof that they were used to store waste. At the edge of the dwelling areas, however, in this period appear "ashmounds" (essentially the same as middens), which contain waste from this period, including bronze fragments. Dietrich considers them to be structured deposits, which supposedly originated with the deposition of materials created as the result of a specific activity - the author theorizes about possible feasts and refers to these findings as "holy garbage dumps" (Dietrich, 2016).

Middens are another type of deposition-based waste strategy, one based on substantially greater functional homogeneity of waste material. These sites are defined as areas consisting mainly of disposed domestic rubbish and in some cases a certain symbolic function has been attributed to them, one beyond just a simple waste disposal site (see Needham \& Spence, 1997).

The variability of waste in middens is relatively broad. They contain mostly animal bones, shells, general kitchen waste, human and animal excrement, plant residue, shards, and stone chippings. It is, of course, possible to find other types of artefacts and ecofacts. There are three possible theories for how the East Chisenbury midden in Britain was created. The first possibility is that it is an accumulation of waste from dwellings. The second is that it is the result of occasional, but massive, disposal of a large amount of meat, ceramic used for preparing and serving food, and bedding for animals and humans alike (McOmish, 1996). 
The third possibility is that the midden contains waste produced elsewhere that was then taken to this site (McOmish et al., 2010), a theory that fits Neustupný's definition of "tertiary waste" (2007). It is also of course possible that the midden is the result of a combination of all or some of these theories. Tubb, for example, states that this waste could have hypothetically been created as the product of lively celebrations of some sort and the midden is thus a material reminder of such events (Tubb, 2011).

Thus, the midden could essentially reflect the community's wealth. By demonstrating the size of the midden itself the symbolic wealth of the community that made it would grow. The fact that middens are usually located in elevated areas would support this explanation (Tubb, 2011). If this is the case, then disposing waste would have been a socially important activity. According to Tubb, the creation of middens reflected a certain type of social competitiveness and he rejects the view of East Chisenbury as a mere waste disposal site (Tubb, 2011).

The case of the East Chisenbury midden exposes one simple fact - that it is difficult to define and categorize historic waste. Considering the fact that we do not know the social environment in which these waste dumps were created, their importance for the society that created them can hardly be determined. Thus, it is worth a reminder that when we interpret historic waste, we often project our own subjective view on this issue, which distorts the objective reality.

However, it is necessary to mention one more important phenomenon-human remains found in Bronze Age settlement pits. From a purely technically standpoint, they may have been waste, but it is difficult to distinguish minor nuances in symbolic or ritual behavior, when only material sources are available. Considering the complex nature of non-ritual burial of human remains in the Bronze Age, which likely may have included some elements of cannibalism, punishment, or general ritual or religious behavior, we shall not analyze this question here. Many articles and books could be written about this topic.

\section{CONCLUSION}

Even though we have described several cases of Bronze Age waste management, it is still complicated to provide a summary or categorization of waste behaviors throughout the entire period. It is necessary to note that waste is always part of the metabolism of human culture and thus it is inseparable from human society.

Every period brings technological changes, which are then reflected in the composition or amount of waste. The Bronze Age was the end of the prehistoric period; the following Iron Age is traditionally considered a period of protohistory. The spread of metalworking technology definitely made a significant contribution to waste issues due to the difficulties of mining and processing this material.

In the historical context, and from a purely material perspective, waste associated with metallurgy was likely the only change in comparison with the previous Paleolithic and Neolithic periods.

\section{REFERENCES}

Angelakis, A. N., \& Zheng, X. Y. (2015). Evolution of water supply, sanitation, wastewater, and stormwater technologies globally.

Angelakis, A. N., Kavoulaki, E., \& Dialynas, M. G. (2014). Sanitation and stormwater and wastewater technologies in Minoan Era. Evolution of Sanitation and Wastewater Management through the Centuries. 
Bąbel, J. T. (2008). Krzemionki Opatowskie the earliest beginnings of modern mining. The mine as a witness to history and a monument of technology, 21.

Barfield, L., \& Hodder, M. (1987). Burnt mounds as saunas, and the prehistory of bathing. Antiquity, 61(233), 370-379.

Ben-Yosef, E., Ron, H., Tauxe, L., Agnon, A., Genevey, A., Levy, T. E., \& Najjar, M. (2008). Application of copper slag in geomagnetic archaeointensity research. Journal of Geophysical Research: Solid Earth, 113(B8).

Bilitewski B, Härdtle G, Marek K, Weissbach A and Boeddicker H. (1997). Waste management. Springer-Verlag, Berlin, Heidelberg, Germany.

Blažek, J., Ernée, M., Smejtek, L. (1998). Die bronzezeitlichen Gussformen in Nordwestböhmen. Most.

Budd, P., Taylor, T. (1995). The faerie smith meets the bronze industry: magic versus science in the interpretation of prehistoric metal-making, World Archaeology 27/1, 133-143.

Dietrich, L. (2016). Purity and holy dumps of garbage: organising rubbish disposal in the Middle and Late Bronze Age of the Carpathian Basin. In Sosna, D., \& Brunclíková, L. (2016). Archaeologies of Waste: Encounters with the unwanted.

Dobeš, M. (2013). Méd'veneolitických Čechách. Dissertationes archaeologicae Brunenses/Pragensesque; 16. Praha.

Dobeš, M., Fojtík, P., Kalábek, M., Kalábková, P., Peška, J. (2010). K počátkům výskytu měděné industrie na Moravě. Sekery z Hulína-Pravčic a Laškov-Kandie. Přehled výzkumů 51, 49-60.

Gumiński, W. (1989). Gródok Nadbużny. Osada kultury pucharów lejkowa-tych, Wroclav-Warszawa-Kraków-Gdaňsk-Łodź.

Grattan, J. P., Adams, R. B., Friedman, H., Gilbertson, D. D., Haylock, K. I., Hunt, C. O., \& Kent, M. (2016). The first polluted river? Repeated copper contamination of fluvial sediments associated with Late Neolithic human activity in southern Jordan. Science of The Total Environment, 573, 247-257.

Harding, A., \& Fokkens, H. (Eds.). (2013). The Oxford Handbook of the European Bronze Age. OUP Oxford.

Havlíček, F. (2015). Waste Management in Hunter-Gatherer Communities. Journal of Landscape Ecology, Vol: 8, 47-59.

Havlíček, F., \& Kuča, M. (2017). Waste management at the end of the Stone Age. Journal of Landscape Ecology. In press.

Karageorghis, V., \& Kassianidou, V. (1999). Metalworking and recycling in Late Bronze Age Cyprus-the evidence from Kition. Oxford Journal of Archaeology, 18(2), 171-188.

Kristiansen, K., \& Larsson, T. B. (2005). The rise of Bronze Age society: travels, transmissions and transformations. Cambridge University Press.

Kuna, M., \& Němcová, A. (2012). Výpověd’ sídlištního odpadu. Nálezy z pozdní doby bronzové $v$ Roztokách a otázky depozični analýzy archeologického kontextu. Praha: Archeologický ústav AVČR.

McOmish, D., Field, D., \& Brown, G. (2010). The Late Bronze Age and Early Iron Age midden site at East Chisenbury, Wiltshire. Wiltshire Archaeological and Natural History Magazine, 103, 35-101.

Melosi, M. V. (2004). Garbage in the Cities: Refuse reform and the Environment. University of Pittsburgh Pre. 
Murdock, G. P. (1945). The common denominator of cultures. In R. Linton (Ed.), The science of man in world crisis. New York: Columbia University Press.

Needham, S., \& Spence, T. (1997). Refuse and the formation of middens. Antiquity, 71(271), 77-90.

Neustupný, E. (2007). Metoda archeologie. Vydavatelství a nakladatelství Aleš Čeněk.

Obereder, J., Pernicka, E., Ruttkay, E. (1993). Die Metallfunde und die Metalurgie der kupferzeitlichen Mondseegruppe. Ein Vorbericht, Archeologie Österreichs 4/2, 5-9.

Oliva, M. (2010). Pravěké hornictví v Krumlovském lese. Vznik a vývoj industriálně-sakrální krajiny na jižní Moravě. Prehistoric mining in the "Krumlovský les » (Southern Moravia). Origin and development of an industrial-sacred landscape. Anthropos 32 /N.S. 24/, 472pp.

Peters, J., \& Schmidt, K. (2004). Animals in the symbolic world of Pre-Pottery Neolithic Göbekli Tepe, south-eastern Turkey: a preliminary assessment. Anthropozoologica, 39(1), 179-218.

Pichtel, J. (2005). Waste management practices: municipal, hazardous, and industrial. CRC press.

Podborský, V. (1997). Dějiny pravěku a rané doby dějinné. Ústav Archeologie a Muzeologie, Filozofická Fakulta Masarykovy Univerzity.

Rožnovský, D., Šmíd, M. (2013). Objekt kultury nálevkovitých pohárů s doklady metalurgie mědi z obce Dyje, okr. Znojmo. Pravěk NŘ 23, 35-55.

Schenk, Z., Kuča, M., Hložek, M., Dočkalová, M., Dreslerová, G., Gregerová, M., Krupa, P., Trojek, T. (2007). Pohřeb kultury s moravskou malovanou keramikou z polohy „Dolni újezd" na katastru Dluhonic (okr. Přerov). Předběžná zpráva. Ročenka 2007. Archeologické centrum v Olomouci, př́íspěvková organizace. Olomouc, 38-56.

Sommer, U. (1990). Dirt theory, or archaeological sites seen as rubbish heaps. Journal of theoretical Archaeology, 1, 47-60.

Podborský, V. (2006). Náboženství pravěkých Evropanů. Masarykova Univ., Brno.

Schiffer, M. B. (1976). Behavioral archaeology. University of Utah Press. Salt Lake City.

Sherratt, A. (1997). Economy and society in prehistoric Europe: changing perspectives. Edinburgh: Edinburgh University Press.

Stålbom, U. (1997). Waste or what? Rubbish pits or ceremonial deposits at the Pryssgården site in the Late Bronze Age. Lund Archaeological Review, 1997, 21-36.

Tammemagi, H. Y. (1999). The waste crisis: landfills, incinerators, and the search for a sustainable future. Oxford University Press.

Točík, A., Bublová, H. (1985). Príspevok k výskumu zaniknutej t’ažby medi na Slovensku, Študijné zvesti archeologického ústavu slovenskej akadémie vied 21, 47-135.

Tubb, P. C. (2011). Late Bronze Age/Early Iron Age transition sites in the Vale of Pewsey: the East Chisenbury midden in its regional context. Wiltshire Archaeological and Natural History and Magazine, 104, 44-61.

Wilson, A. L. (1977). The place-names in the Linear B tablets from Knossos: some preliminary considerations. Universidad de Salamanca. 